\title{
HEMOLYMPH PH AS A MARKER OF PESTICIDE EXPOSITION
}

\section{ODCZYN HEMOLIMFY JAKO WSKAŹNIK EKSPOZYCJI NA PESTYCYDY}

\author{
Department of Animal Toxicology, Nicolaus Copernicus University, Toruń \\ ${ }^{1}$ Department of Biophysics, Nicolaus Copernicus University, Toruń
}

\begin{abstract}
Streszczenie. Działanie toksyny wpływa na zachwianie równowagi procesów fizjologicznych przebiegających wewnątrz organizmu. Zmiany w parametrach biochemicznych krwi odzwierciedlają zaburzenia w procesach metabolicznych przebiegających w organizmie, wynikających z działania zanieczyszczeń. W przypadku owadów, u których hemolimfa wypełnia całą jamę ciała, zaburzenia pojawiające się w organizmie są odzwierciedlane w zmianie jej parametrów. Celem doświadczeń była ocena możliwości wykorzystania odczynu hemolimfy owada jako markera wskazującego na zatrucie insektycydami. Badania przeprowadzono na dorosłych osobnikach mącznika młynarka, poddanych działaniu insektycydów o różnych mechanizmach działania owadobójczego, w różnej temperaturze otoczenia $\left(15^{\circ} \mathrm{C}, 25^{\circ} \mathrm{C}\right.$ i $\left.35^{\circ} \mathrm{C}\right)$. Oprócz badania odczynu hemolimfy określano śmiertelność intoksykowanych owadów po 3 dobach od aplikacji pestycydów. Wyniki wskazują na istnienie zależności pomiędzy odczynem hemolimfy a śmiertelnością badanych owadów. Aplikacja insektycydów skutkowała spadkiem odczynu hemolimfy - im spadek był większy, tym wyższą notowano śmiertelność. Uzyskane wyniki wskazują na możliwość wykorzystania odczynu hemolimfy jako wskaźnika narażenia organizmu na insektycydy.
\end{abstract}

Key words: hemolymph, insecticides, mortality, pH, Tenebrio molitor.

Słowa kluczowe: hemolimfa, insektycydy, śmiertelność, pH, Tenebrio molitor.

\section{INTRODUCTION}

Insects have an open blood system with hemolymph occupying the general body cavity. The hemolymph circulates round the body and baths tissues directly. It consists of hemocytes suspended in fluid plasma, which carries many chemicals that are provided for the tissues (Chapman 2007). The main hemolymph component is water, which makes up 20 to $50 \%$ of the total water in insect bodies, therefore serving as a water storage or hydraulic fluid. Insects hemolymph is characterized by high concentration of free amino acids (Resh and Cardé 2003). The fluid plasma contains also lipids, carbohydrates, biogenic amines, hormones and inorganic constituents, of which the most abundant anion is chloride (Chapman 2007).

The $\mathrm{pH}$ of insect hemolymph ranges between 6.4 and 7.5. Many insect physiological processes depend on hemolymph acid-base status, therefore its regulation is one of the most crucial aspect of homeostasis of the organism. Hemolymph $\mathrm{pH}$ affects enzyme activities, epithelial transport of nutrients, membrane potentials and many more (Harrison 2001). Early

Corresponding author - Adres do korespondencji: Justyna Maliszewska, Department of Animal Toxicology, Nicolaus Copernicus University, Lwowska, 187-100 Toruń, Poland, e-mail: ojustyna@umk.pl 
observations indicated that the buffering capacity of insect blood differs from that observed in vertebrates and is low in the normal physiological range, but increases in low and high $\mathrm{pH}$ (Levenbook 1950). Recently, it was shown that insects hemolymph pH changes are less than 1 unit even during activity. This means that only compounds which buffer in $\mathrm{pH}$ range of 6.3-7.3 are involved in insects acid-base regulation, and the buffering capacity of insect hemolymph is generally similar to that of vertebrates. The major buffer system during nonrespiratory $\mathrm{pH}$ alternations are bicarbonates (57\% total buffer value of the hemolymph). The primary nonbicarbonate buffers in the hemolymph are proteins $(66 \%)$, total phosphates $(20 \%)$, citrate and histidine (3\%) - Harrison et al. (1990). Apart from mobilization of blood buffer compounds, recovery from acid-base disturbances may result from excretion of acid equivalents by epithelial transport or ventilatory adjustment (Harrison et al. 1992).

Hemolymph circulates in direct contact with the animals's tissues, therefore every disruption that appears in the body is reflected in change of hemolymph parameters. When the organism is exposed to contamination, changes in hemolymph $\mathrm{pH}$ may be observed. Sublethal doses of copper induced decrease of blood pH from 7.8 to 7.45 in shore crabs Carcinus means L. (Boitel and Truchot 1989). Hemolymph pH decreased significantly in prawns Macrobrachium rosenbergii (de Man) exposed to organophosphate pesticide trichlorfon (Yeh et al. 2005). American cockroach Periplaneta americana L. also showed significant changes in hemolymph pH after pyrethroid exposure (Adamkiewicz et al. 2012). However, this subject seems to be neglected, since data concerning the effects of toxins on hemolymph $\mathrm{pH}$ are very limited.

The aim of this study was to evaluate whether hemolymph $\mathrm{pH}$ may be a marker of pesticide exposition in insects. It is especially important in case of sublethal doses of xenobiotics, when no mortality is observed, but the chemicals still affect organisms physiology. The question arises whether there could be a correlation between changes in blood $\mathrm{pH}$ and mortality after exposition to pesticides.

\section{MATERIAL AND METHODS}

\section{Insects}

Experiments were performed on adult individuals of mealworm Tenebrio molitor L., both sexes. Insects were kept at plastic containers $(32 \times 20 \times 20 \mathrm{~cm})$ filled with flour, oat flakes and cottonwool. Containers were kept in $25^{\circ} \mathrm{C}$ and $12: 12 \mathrm{~L}: \mathrm{D}$. Insect were fed with slices of apple.

\section{Insecticides}

Four different insecticides with distinct mode of insecticidal action were used in this study:

1. Pyrethroid Bulldock 025 EC (Makteshim Agan Industries Ltd, Israel) with ß-cyfluthrin $(2.75 \%)$ as an active substance (dose used in this study: $0.0004 \mu \mathrm{g} / \mathrm{mealworm}$ ).

2. Oxadiazine Steward 30 WG (Du Pont de Nemours, USA) with indoxacarb (30\%) as an active substance (dose used in this study: $1 \mu \mathrm{g} / \mathrm{insect}$ ).

3. Neonicotinoid Mospilan 20 SP (Nisso Chemical Europe, Germany) with acetamiprid as an active substance (dose used: $0.25 \mu \mathrm{g} / \mathrm{insect}$ ).

4. Organophosphate Actellic 500 EC (Syngenta Crop Protection, Switzerland) with pirimiphos-methyl as an active substance (dose used: $0.0008 \mu \mathrm{g} / \mathrm{mealworm}$ ). 
Doses of the insecticides were estimated as $\mathrm{LD}_{50}$ in a preliminary study at $25^{\circ} \mathrm{C}$ (standard procedure for testing chemical toxicity).

\section{$\mathrm{pH}$ of the hemolymph}

$\mathrm{pH}$ of the mealworm hemolymph was determined after 72 hours from insecticides application. There was only one exception - in $35^{\circ} \mathrm{C}, 100 \%$ mortality was observed after 72 hours from exposition to neonicotinoid insecticide, therefore $\mathrm{pH}$ of the hemolymph was determined after 24 hours. Hemolypmph was obtained from the decapitated individuals, only from living insects. Hemolymph $\mathrm{pH}$ was measured on $10 \mu$ samples collected with glass microcapillary tubes. Samples were immediately transferred to the Eppendorf tubes and measured with glass microelectrode (PHR-146B Micro combination electrode; Cole-Parmer, Chicago, IL, USA) connected to $\mathrm{pH}$-meter (pH 1100 Bench pH/lon Meter; Oakton Instruments, Vernon Hills, IL, USA). This microelectrode allows to measure $\mathrm{pH}$ of samples as low as $10 \mu \mathrm{l}$ with accuracy to $\pm 0.01 \mathrm{pH}$. $\mathrm{pH}$-meter was calibrated with standard calibration buffers before each experimental series.

It is important to consider whether $\mathrm{CO}_{2}$ loss from the hemolymph during the measurement allows to accurate measure haemolymph $\mathrm{pH}$. Because of lack of carbonic anhydrase in insects haemolymph, some air exposure is tolerable (Harrison 2001). Since samples of mealworms heamolymph was measured immediately after collecting, loss of $\mathrm{CO}_{2}$ was minimal and should not significantly affect haemolymph $\mathrm{pH}$. Harrison et al. (1992) demonstrated that if $\mathrm{pH}$ was measured within five minutes, loss of $\mathrm{CO}_{2}$ was not detectable.

\section{Insect mortality}

The mortality of the examined mealworms was monitored in three different ambient temperatures $-15^{\circ} \mathrm{C}, 25^{\circ} \mathrm{C}$ and $35^{\circ} \mathrm{C}$ for 72 hours. Mealworms were exposed to $10 \mu \mathrm{l}$ of insecticide solutions, which were applied topically on the ventral part of prothorax. Control group received only water. After exposition, insects were placed in glass containers, which were kept in specified ambient temperature and 12:12 L : D in laboratory incubator ILW 15 STD (POL-EKO APARATURA, Wodzisław Śląski, Poland). Each experimental series consisted of six different individuals and was repeated six times (total: 36 insect per each experimental series - i.e. per each insecticide; jointly it was 15 groups, each with 36 individuals). The insect had free access to food (apple slices).

\section{Statistical analysis}

To test whether insecticide treatment in different ambient temperatures affected hemolymph $\mathrm{pH}$ and mortality of mealworms, two-way analysis of variance with Bonferroni correction for pairwise comparisons was applied with the following factors: (1) insecticide and (2) temperature. Before analysis, all data were and tested for normality (Kolmogorov-Smirnov test) and homogeneity of variance (Levene's test). Data concerning insect mortality were arcsine square root transformed.

To test whether there is a relationship between hemolymph $\mathrm{pH}$ and mortality after intoxication with insecticides, Pearson correlation was applied. The level of significance for all test was 0.05. Analyses were performed in IBM SPSS Statistics 22 software. Data are presented as mean \pm SD. 


\section{RESULTS}

Intoxication with insecticides resulted in significant decrease of hemolymph $\mathrm{pH}$ in mealworms, independently of ambient temperature. It also resulted in significant mealworm mortality (Table 1).

Table 1. Results of two-way ANOVA with insecticides and temperature as fixed factors, with Bonferroni correction for pairwise comparisons

Tabela 1. Wyniki dwuczynnikowej analizy wariancji z ekspozycją na insektycydy oraz temperaturą otoczenia jako czynnikami stałymi, z uwzględnieniem poprawki Bonferroniego dla porównań wielokrotnych

\begin{tabular}{|c|c|c|c|c|c|}
\hline \multicolumn{6}{|c|}{$\mathrm{pH}$ of the hemolymph - Odczyn hemolimfy } \\
\hline Factor - Czynnik & d.f. & SS & MS & $\begin{array}{c}\text { F-ratio } \\
\text { wartość testu } F\end{array}$ & $\begin{array}{l}\text { P-value } \\
\text { istotność }\end{array}$ \\
\hline $\begin{array}{l}\text { Insecticide } \\
\text { Insektycyd }\end{array}$ & 4 & 0.848 & 0.212 & 15.514 & $<0.001$ \\
\hline $\begin{array}{l}\text { Temperature } \\
\text { Temperatura }\end{array}$ & 2 & 0.651 & 0.325 & 23.803 & $<0.001$ \\
\hline $\begin{array}{l}\text { Interaction } \\
\text { Interakcja }\end{array}$ & 8 & 1.012 & 0.127 & 9.26 & $<0.001$ \\
\hline Error - Błąd & 216 & 2.952 & 0.014 & & \\
\hline \multicolumn{6}{|c|}{ Mortality - Śmiertelność } \\
\hline Factor - Czynnik & d.f. & SS & MS & $\begin{array}{c}\text { F-ratio } \\
\text { wartość testu } F\end{array}$ & $\begin{array}{l}\text { P-value } \\
\text { istotność }\end{array}$ \\
\hline $\begin{array}{l}\text { Insecticide } \\
\text { Insektycyd }\end{array}$ & 4 & 23293 & 5823 & 22.952 & $<0.001$ \\
\hline $\begin{array}{l}\text { Temperature } \\
\text { Temperatura }\end{array}$ & 2 & 35627 & 17813 & 70.209 & $<0.001$ \\
\hline $\begin{array}{l}\text { Interaction } \\
\text { Interakcja }\end{array}$ & 8 & 11180 & 1397 & 5.508 & $<0.001$ \\
\hline Error - Błąd & 75 & 19029 & 253 & & \\
\hline
\end{tabular}

d.f. - degrees of freedom - liczba stopni swobody.

SS - sum of squares - typ III sumy kwadratów.

MS - mean square - średni kwadrat.

Hemolymph pH of not treated mealworms ranged between $6.96 \pm 0.05$ in $15^{\circ} \mathrm{C}$ to $6.91 \pm 0.08$ in $35^{\circ} \mathrm{C}$ (Fig. 1). After pyrethroid exposure, it decreased to $6.81 \pm 0.15$ in warm $\left(25^{\circ} \mathrm{C}\right.$ and $\left.35^{\circ} \mathrm{C}\right)$ and $6.91 \pm 0.08$ in cold (pairwise comparison with Bonferroni correction: $P=0.001$ versus control group). The highest mortality of pyrethroid-treated mealworms was observed in $25^{\circ} \mathrm{C}$ $(38.5 \pm 9.4 \%)$, although it was only a little bit lower in $35^{\circ} \mathrm{C}(33.3 \pm 9.6 \%)$.

Oxadiazine treatment resulted in $\mathrm{pH}$ drop from $6.89 \pm 0.04$ in $15^{\circ} \mathrm{C}$ to $6.75 \pm 0.09$ in $35^{\circ} \mathrm{C}$ (pairwise comparison with Bonferroni correction: $\mathrm{P}<0.001$ versus control group). This insecticide revealed positive temperature coefficient of toxicity, inducing fourfold increase in mealworms mortality between $25^{\circ} \mathrm{C}$ and $35^{\circ} \mathrm{C}$. Mealworms intoxicated with neonicotinoid also revealed significant increase in mortality with rise of ambient temperature. In $35^{\circ} \mathrm{C}, 100 \%$ mortality was observed after 72 hours from exposition, therefore $\mathrm{pH}$ of the hemolymph was determined after 24 hours. Even then, there was a significant decrease of hemolymph pH $(6.76 \pm 0.07 ; 33 \%$ mortality). In case of organophosphate insecticide, the highest $\mathrm{pH}$ decrease was observed in $25^{\circ} \mathrm{C}-6.5 \pm 0.3$ with $60.6 \pm 3.7 \%$ mortality. However, in $35^{\circ} \mathrm{C}$, very high mortality was observed $-91.7 \pm 5.7 \%$ and the results of hemolymph $\mathrm{pH}$ are obtained only from individuals that survived. This could affect the result observed $\left(\mathrm{pH}=6.94 \pm 0.04\right.$ in $\left.35^{\circ} \mathrm{C}\right)$. 


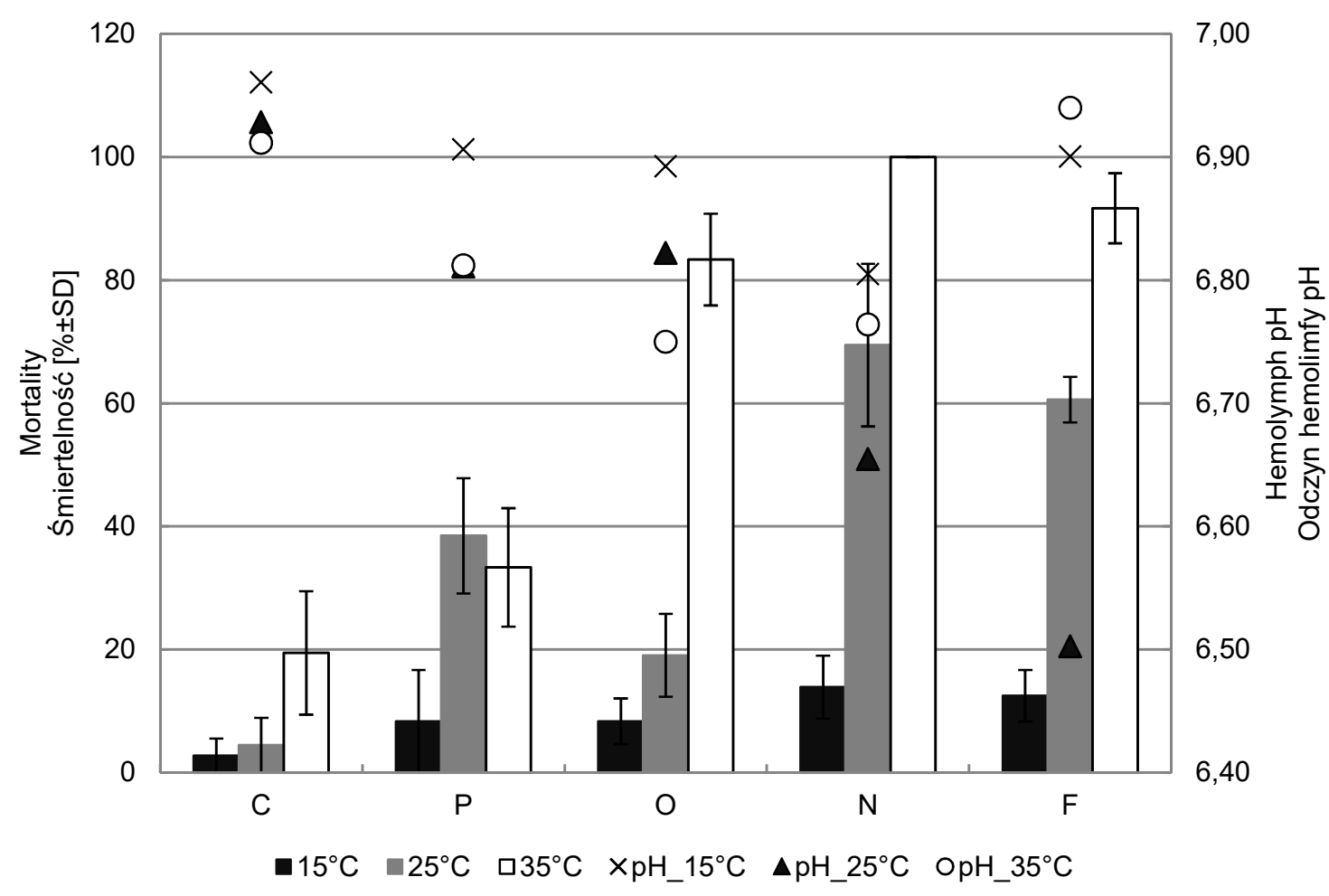

Fig. 1. Mortality $(\% \pm S D)$ (bars graph) and $\mathrm{pH}$ of the hemolymph (scatter plot) of mealworms treated with water $(C)$, pyrethroid $(P)$, oxadiazine $(O)$, neonicotinoid $(N)$ and organophosphate $(F)$, after 72 hours from exposition

Ryc. 1. Śmiertelność (\%₫SD) (wykres słupkowy) oraz odczyn hemolimfy (wykres punktowy) mącznika młynarka eksponowanego na wodę $(C)$, pyretroid $(P)$, oksadiazynę $(O)$, neonikotynoid $(N)$ i insektycyd fosforoorganiczny $(\mathrm{F})$, po 72 godzinach od ekspozycji

Analysis revealed that there is a significant correlation between mealworms mortality and $\mathrm{pH}$ of the hemolymph after insecticide exposure. High decrease of $\mathrm{pH}$ was observed in the heat $\left(35^{\circ} \mathrm{C}\right)$, where mortality was the highest (Pearson correlation: $r=-0.395, P=0.046$ ). Also in $25^{\circ} \mathrm{C}$ there was a negative correlation between mortality and $\mathrm{pH}$ (Pearson correlation: $r=-0.399, P=0.035)$. In cold $\left(15^{\circ} \mathrm{C}\right)$ changes in both hemolymph $\mathrm{pH}$, as well as in mortality was the least.

\section{DISCUSSION}

Our results indicate that a $\mathrm{pH}$ of the hemolymph could serve as a marker of pesticide exposition in insects.

After intoxication many physiological processes become disturbed which results in homeostasis disruption. Changes in blood biochemical parameters reflect metabolic disorders that occur after exposition to contaminants or xenobiotics. Insects hemolymph moves through the open circulatory system, directly bathing tissues and organs. Therefore any disorders that occur after poisoning are reflected in changes of hemolypmh parameters.

Nath (2000) showed that insects' exposition to insecticides influence normal functioning of the hemolymph through changes in metabolite synthesis and enzymes activities. Exposition to lethal and sublethal doses of organophosphate insecticides disturbs the carbohydrate 
metabolism of hemolymph in silkworm Bombyx mori L. Decrease in puryvate and increase in lactate levels were observed, which suggest the predominance of anaerobic glycolysis and shift form aerobic to anaerobic metabolism to meet the required energy demands after intoxication (Nath 2000). Moreover, silkworm exposed to organophosphates demonstrated elevated levels of trehalose and glucose in hemolymph and increase in trehalase activity suggesting breakdown of homeostatic mechanism coupled with glycogenolysis (Nath 2003). Insecticides induced also changes in protein metabolism in silkworm, eliciting severe proteolysis and transamination of amino acids (Nath et al. 1997). Cypermethrin (pyrethroid) were shown to affect activity of alkaline phosphatase, acid phosphatase and ATPase in grasshopper Chrotogonus trachypterus (Shakeet and Bakshi 2010). Similarly, cypermethrin and bifenthrin exposure affected activity of acid and alkaline phosphatases in red flour beetle Tribolium castaneum (Ahmed et al. 2004).

All these disorders in enzyme activities and metabolites levels induced by exposition to insecticides may determine changes in $\mathrm{pH}$ of the hemolymph. The results obtained demonstrate that pesticides elicit $\mathrm{pH}$ decrease in mealworms. Despite the fact that $\mathrm{pH}$ was measured three days after exposition to insecticides, significant reduction of hemolymph $\mathrm{pH}$, irrespectively of ambient temperature, was observed. This suggests severe disruption of organismal homeostasis in intoxicated insects.

Decrease in hemolymph pH may be not only the result, but also a reason for changes in metabolic pathways. High energy demand that occur after exposition to contaminants may lead to lactate accumulation in hemolymph, which was shown in silkworm (Nath 2000), and this would affect hemolymph $\mathrm{pH}$. Insecticides may affect capacity of blood buffer compounds. The primary nonbicarbonate buffers in the hemolymph are proteins, which levels in hemolymph may be reduced after intoxication. This may diminish blood buffering capacity and impede recovery from acid-base disturbances.

We observed a significant correlation between changes in hemolymph $\mathrm{pH}$ and mortality in mealworms exposed to insecticides. The reaction of insects was non-specific - independently from the mechanism of insecticidal action, the shift in $\mathrm{pH}$ was similar (decrease). Moreover, correlation has a negative coefficient - the lower $\mathrm{pH}$ was determined, the higher mortality was observed. This lead to conclusion that changes in hemolymph $\mathrm{pH}$ may serve as effective biomarker of intoxication with pesticides level in insects.

\section{CONCLUSSIONS}

Intoxication with insecticides results in hemolymph $\mathrm{pH}$ decrease, which is correlated with insects mortality. Hemolymph $\mathrm{pH}$ may serve as a marker of organism exposition to pesticides.

\section{REFERENCES}

Adamkiewicz B., Tęgowska E., Grajpel B., Olszewska J. 2012. How capsaicin changes the toxicity of pyrethroids in American cockroach (Periplaneta americana). Ecol. Chem. Eng., A 19, 1263-1270.

Ahmed S., Saleem M.A., Shahzad R.K. 2004. Effect of cypermethrin (10EC) and bifenthrin (10EC) on levels of acid and alkaline phosphatases in a strain of Tribolium castaneum (Herbst) (Coleoptera:Tenebrionidae). Pak. Entomol. 26, 47-52. 
Boitel F., Truchot J.P. 1989. Effects of sublethal and lethal copper levels on hemolymph acid-base balance and ion concentrations in the shore crab Carcinus maenas kept in undiluted sea water. Mar. Biol. 103, 495-501.

Chapman R.F. 2007. The insects. Structure and function. New York, Cambridge University Press.

Harrison J.F. 2001. Insect acid-base physiology. Annu. Rev. Entomol. 46, 221-250.

Harrison J.F., Wong C.J.H, Phillips J.E. 1992. Recovery from acute haemolymph acidosis in unfed locusts. J. Exp. Biol. 165, 85-96.

Harrison J.F., Wong C.J.H., Phillips J.E. 1990. Haemolymph buffering in the locust Schistocerca gregaria. J. Exp. Biol. 154, 573-579.

Levenbook L. 1950. The physiology of carbon dioxide transport in insect blood. III. The buffer capacity of Gastrophilus blood. J. Exp. Biol. 27, 184-191.

Nath B.S. 2000. Changes in carbohydrate metabolism in hemolymph and fat body of the silkworm, Bombyx mori L., exposed to organophosphorus insecticides. Pest. Biochem. Physiol. 68, 127-137.

Nath B.S. 2003. Shifts in glycogen metabolism in hemolymph and fat body of the silkworm, Bombyx mori (Lepidoptera: Bombycidae) in response to organophosphorus insecticides toxicity. Pest. Biochem. Physiol. 74, 73-84.

Nath B.S., Suresh A., Varma B.M., Kumar R.P.S. 1997. Changes in protein metabolism in hemolymph and fat body of the silkworm, Bombyx mori (Lepidoptera: Bombycidae) in response to organophosphorus insecticides toxicity. Ecotoxicol. Environ. Saf. 36, 169-173.

Resh H.R., Cardé R.T. 2003. Encyclopedia of insects. 2nd ed. New York, Academic/Elsevier Science, USA.

Shakeet P., Bakhsi S. 2010. Effect of cypermethrin on biochemical parameters on gonads of Chrotogonus trachypterus (Orthoptera - Acrididae). Indian J. Agric. Res. 44, 242-250.

Yeh S.P., Sung T.G., Chang C.C., Cheng W., Kuo C.M. 2005. Effects of an organophosphorus insecticide, trichlorfon, on hematological parameters of the giant freshwater prawn, Macrobrachium rosenbergii (de Man). Aquaculture 243, 383-392.

\begin{abstract}
Changes in blood biochemical parameters reflects disorders in the whole body after exposition to contaminants. Insect hemolymph circulates in direct contact with the animals's tissues, therefore every disruption that appears in the body is reflected in change of hemolymph parameters. The aim of this study was to assess the potential of hemolymph $\mathrm{pH}$ as the marker of insecticide intoxication. Experiments were performed on mealworms Tenebrio molitor L., intoxicated with insecticides' characterized by different mechanisms of insecticidal action pyrethroid, oxadiazine, neonicotinoid and organophospate in different ambient temperatures $\left(15^{\circ} \mathrm{C}, 25^{\circ} \mathrm{C}\right.$ and $\left.35^{\circ} \mathrm{C}\right)$. Hemolymph $\mathrm{pH}$ and insects' mortality after intoxication was assessed after three days from insecticides application. The results obtained showed a correlation between mortality and $\mathrm{pH}$ of the hemolymph. Intoxication with insecticides resulted in $\mathrm{pH}$ decrease: the greater decline was determined, the higher mortality was observed. The results indicate that hemolymph $\mathrm{pH}$ may be used as a marker of organism exposition to xenobiotics.
\end{abstract}

This work was funded by statutory funds of Nicolaus Copernicus University No. 182/2017. 
